\title{
Minimizing Students' Anxiety In Learning Speaking English
}

\author{
Fazlur Rohman \\ Universitas Muhammadiyah Malang, Jawa Timur, Indonesia \\ Malang \\ E-mail: fazlur@yahoo.com
}

Received: January 102019

Accepted: January 172019

Published: February 9, 2019

Doi : http://dx.doi.org/10.30587/jetlal.v3i1.2437

\begin{abstract}
Many students, when they learn speaking English, tend to be silent and just listen what the teacher are saying. They do not have willingness to communicate each other or to the teacher. They just want to speak up when the teacher asks them about something. They have a hunch that they fear if their friends will be laughed them when they will have some mistake in speaking, feel nervous when they have to begin the speaking and their vocabularies are limited. When the students have a situation like that, it can make the students have not been able to speak effectively. These situations are about students' anxiety. Anxiety is about fear, worry, nervous, and self doubt. When speaking class cannot run well because of students' anxiety, the activity cannot run as well as the teacher has planned before. It will be out of plan and a serious condition because speaking is a crucial part of communication in which students learn language by interacting during the lesson. Conducting communicative tasks is recommended by the writer because it can minimize students' anxiety in learning speaking English because it is interesting. The students can feel happy and enjoy the learning activity. The students can explore their language especially in English. There is no restriction on the language used here. Students can practice the language directly in the real life in their classroom activity spontaneously. Interaction between teacher and students and among the students can be created.
\end{abstract}

Keyword: Minimizing students' anxiety, learning speaking

\section{Introduction}

One of four skills in English is speaking. According to Chaney (in Kayi, 2006) speaking is the process of building and sharing meaning through the use of verbal and non-verbal symbols, in a variety of contexts. Speaking is a crucial part of communication because students learn language by interacting during the lesson. According to Richards the mastery of speaking skills in English is priority formally in second language or foreign learners. Learners consequently often evaluate their success in language learning as well as the effectiveness of their course on basis of how much they feel they have improved their spoken language proficiency. It proves that speaking is the first thing in communication, but because of unsupported circumstances, it makes our students have not been able to speak effectively.

Many students, when they learn speaking English, tend to be silent and just listen what the teacher are saying. They do not have willingness to communicate each other or to the teacher. They just want to speak up when the teacher asks them about something. They have a hunch that they fear if their friends will be laughed them when they will have some mistake in speaking, feel nervous when they have to begin the speaking and their vocabularies are limited. When the students have a situation like that, it can make the students have not been able to speak effectively. These situations are about students' anxiety.

Scovel (in Brown, 2000; 151) stated that anxiety is related to feelings of uneasiness, frustration, self-doubt, apprehension or worry. Another definition is explained by Spielberger (in Horwitz et al, 1986) anxiety is the subjective feeling of tension, apprehension, nervousness, and worry associated with an arousal of the autonomic nervous system. When speaking class cannot run well because of students fear, worry, nervous, and self-doubt, the activity cannot run as well as the teacher has planned before. It will be out of plan and a serious condition because speaking is a crucial part of communication in which students learn language by interacting during the lesson. Anxiety can affect the communication strategies students employ in language class. That is, the more anxious student tends to avoid attempting difficult or personal messages in the target language (Horwitz at al, 1986). Because of anxiety, students tend to be silent rather than speak up. So the teacher will have some difficulties in arranging situation or activity like what he or she has planned before.

This paper focuses on how to minimize students' anxiety in learning speaking in order to make the students are able to speak effectively. Based on the findings from several researches that have been done by researchers, there are some ways to minimize students' anxiety in learning speaking. They are conducting jigsaw activity (Qian and 
Seepho, 2012) and using drama (Atas, 2014). It means that the teacher has to conduct an interesting activity to minimize anxiety.

\section{Discussion}

a. Anxiety in learning speaking English

Anxiety is about anxiousness. Some experts have explained it. Scovel (in Brown, 2000) stated that anxiety is related with feelings of uneasiness, frustration, self-doubt, apprehension or worry. Another definition is explained by Spielberger (in Horwitz at al, 1986) anxiety is the subjective feeling of tension, apprehension, nervousness, and worry associated with an arousal of the autonomic nervous system. In addition, according to Cambridge English Dictionary, anxiety is an uncomfortable feeling of nervousness or worry about something that is happening or might happen in the future. From both definitions above we can conclude that anxiety is an uncomfortable feeling of nervousness, worry, uneasiness, frustration, doubt, or apprehension that can influence the students' autonomic system when they are learning.

Anxiety can affect communication strategies students employ in language class. That is, the more anxious students tend to avoid attempting difficult or personal messages in the target language (Horwitz et al, 1986). They just keep silent to avoid some mistakes because they worry about their mind or their assumption or perception will be wrong. Actually when someone feels uncomfortable with a particular situation or condition, so his or her autonomic nervous system will be arisen. He or she will be anxious, worry or doubt with something might happen in the future. Because of it, his or her performance will be decrease.

b. Kinds of anxiety

There are two kinds of anxiety based on some experts. They are trait anxiety and state anxiety (Ellis, 2008).

1) Trait anxiety

Scovel defined anxiety as a more permanent predisposition to be anxious. It is perhaps best viewed as an aspect of personality. This kind of anxiety is difficult to change because it is from personality of the learners. It has attached to the characteristics of the learners.

2) State anxiety

Spielberger defined state anxiety as apprehension that is experienced at a particular moment in time as a response to a definite. Because state anxiety just appears when the learners face a particular situation and condition, it can be changed by habituation and setting the condition.

c. Factors of anxiety

Three components of foreign language anxiety have been identified in order to break down the construct into researchable issues (Brown, 2000: 151). They are:

1) Communication apprehension.

2) Fear of negative social evaluation.

3) Test anxiety or apprehension over academic evaluation.

d. Source of anxiety

Merc in his finding revealed six main categories as the sources of foreign language student teacher anxiety: students and class profiles, classroom management, teaching procedures, being observed, mentors, and miscellaneous (Merc, 2011).

In a close review of the literature on anxiety in language learning, at least six potential sources of language anxiety can be identified. Some are associated with the learner, some with the teacher, and some with the instructional practice (Young, 1991). They are:

1) Personal and interpersonal anxiety.

2) Learner beliefs about language learning.

3) Instructor beliefs about language teaching.

4) Instructor-learner interactions.

5) Classroom procedures.

6) Language testing.

From both references, it can be concluded that the sources of anxiety are similar. Actually the sources of anxiety is from the beliefs of teachers and learners, teachers and learners role, the atmosphere of the class, and about language testing or to be observed. Based from finding, the main sources of anxiety are personal and interpersonal anxiety, personal belief about language learning, instructor-learner interaction, classroom procedures, and language testing (Oktaviani at al, 2013). 


\section{e. Anxiety related to language learning}

There is less agreement about the relationship between language anxiety and learning. Three different positions can be identified (Ellis, 2008):

1. Anxiety facilitates language learning.

2. Anxiety has a negative impact on language learning.

3. Language anxiety is the result of difficulties with learning than their cause.

It means that anxiety can influence learners' performance and achievement in learning English. Low anxiety effect learners perform better than high anxiety.

f. How to minimize students' anxiety in learning speaking English

Teacher's role is important to motivate the students and facilitate effective and fun learning. Teacher has to be creative in teaching especially teaching speaking because many students feel anxiety when they learn speaking. Teacher has to create enjoying and interesting activity to minimize their anxiety in learning speaking. Minimizing anxiety can be done by conducting an interesting or fun activity. Ewe Lin at al (2014) used fun learning, such as expressive introduction, ten creative ways to use an object, charade, sound story, chocolate vs ice cream, lord Moulton's hair and property, and blindly arrange in order, to minimize their students' anxiety in speaking. In their finding found that the games could minimize their students' anxiety in speaking.

Thornburry (2005) used communicative tasks in teaching speaking. Communicative tasks fulfill two important language learning needs, they prepare learners for real-life language use and they encourage the automization of language knowledge.

The characteristics of communicative tasks are (Thornburry, 2005):

a. The motivation of the activity is to achieve some outcome, using language.

b. The activity takes place in real time.

c. Achieving the outcome requires the participants to interact, i.e. to listen as well as speak.

d. Because of the spontaneous and jointly constructed nature of the interaction, the outcome is not $100 \%$ predictable.

e. There is no restriction on the language used.

Anxiety can be minimized by conducting communicative tasks because it is interesting. The students can explore their language especially in English because the motivation of the activity is to achieve some outcome. The outcome is using language. There is no restriction on the language used here. Students can practice directly in the real situation and condition in their class to use their own language based on facts. So, students can interact in that activity and speak spontaneously. Interaction among students and also the teacher can be happened. It is proved by conducting an interesting activity can minimize students' anxiety. Qian and Seepho (2012) used jigsaw activity and Atas (2014) used drama activity. Students' anxiety can be minimized because the students feel happy and enjoy during the speaking class.

The types of communicative tasks are:

a. Information gap activity

In information gap activities, the information required to complete the task is distributed amongst the interactants. There is a knowledge gap, therefore, between them, and this can only be bridged by using language. So, in order to achieve the task outcome, the interactants have to communicate.

For example: 


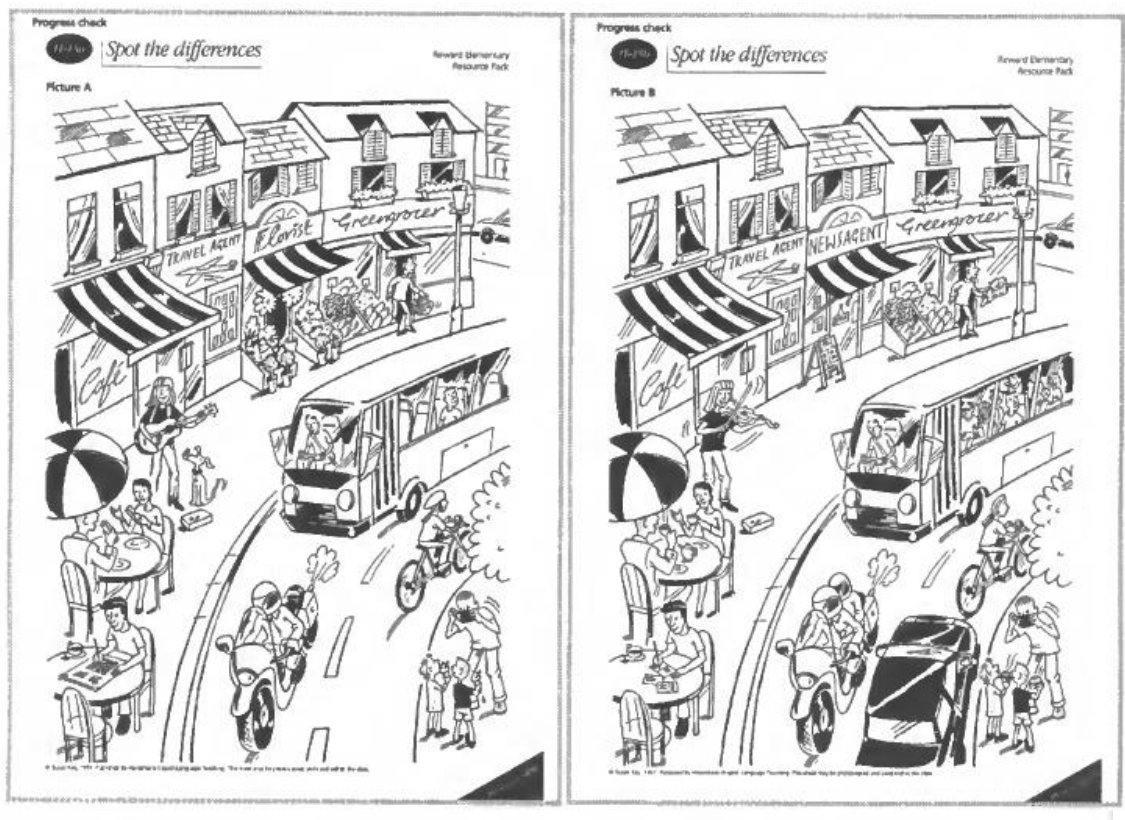

A: Er, near, near, near this man, who play the violin, there is a, a dog?

E: No (No) I don't have a go ..., a dog in my picture.

A: A dog near, OK. Mm. The, the motorbike is, er, is, um, near in, in, in the bottom of the ... you, you are a, a bike of the bottom of the picture?

E: In the bottom?

A: Yeah.

E: $\mathrm{Mm}$... no.

Continues ...
A: No?
E: In my picture, the bike is ...
A: Near the man of ...
E: Near of ...
A: Near one man he stay, er, with, with a pen, in a, in a table. [He said he couldn't remember 'writing'.]
E: Bicycle, or motor ...
A: A motor, motorbike.
E: Yes, is near.
A: Is near, in the bottom of the, of the, of the picture. The bottom, bottom.
E: Yes. Um, sorry, do you have a one man, er, in he hand a flowers?
A: No, it haven't.
E: Is a two difference for me (OK) I think. Um ...

b. Jigsaw activity

Prior to the lesson, the teacher prepares four flashcards, each an enlarged frame from the following picture story. 


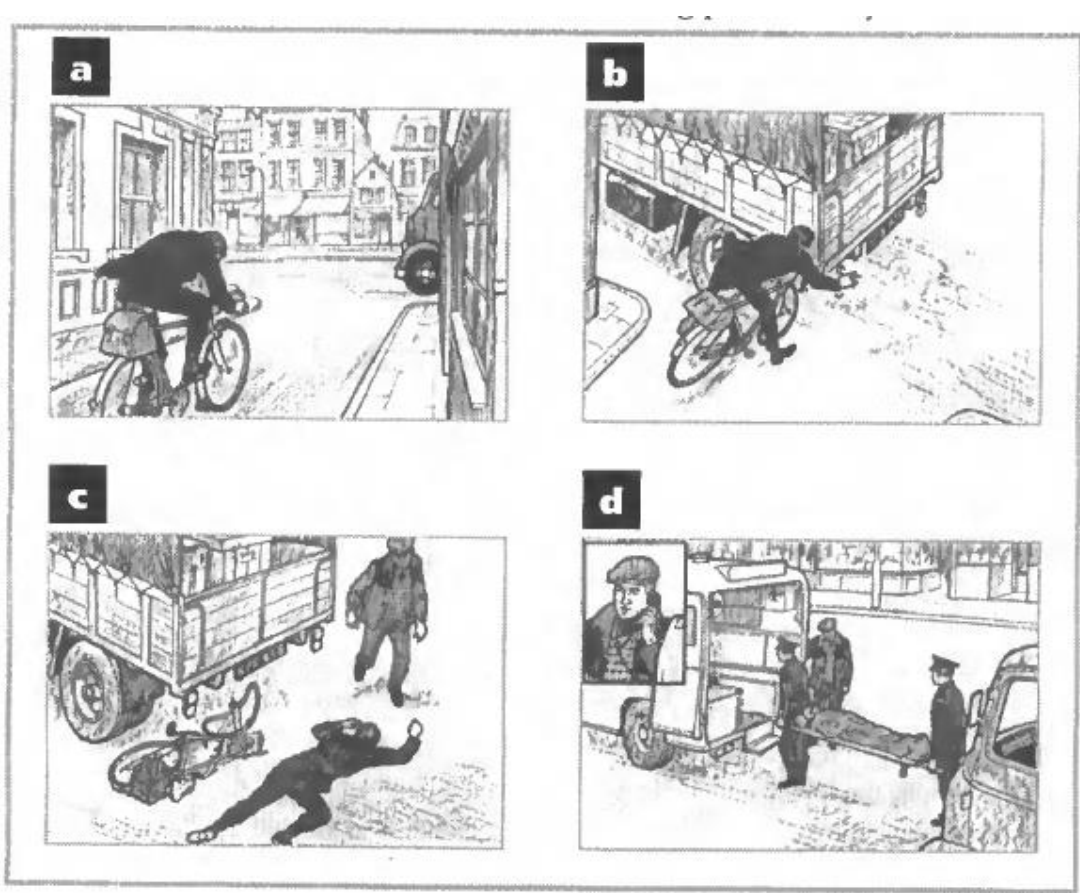

The teacher tells the class they are going to witness a minor traffic accident, but, as in most traffic accidents, it happens very quickly, and they only see the accident from one perspective. The class is divided into four groups and the teacher flashes the pictures, in random order and for a few seconds only, one per group. The members of each group have to then agree, amongst themselves, what it is they have just seen. Then, the members of each group are redistributed, so that new groups are formed that comprise someone from each of the original four groups. (One way of doing this is to give each member of each group a number: 1, 2, 3, and so on. Then all the number ones form a group, and the number twos, and so on). The task of each group is (a) to take it in turns to describe what each person saw, (b) to decide, jointly, the sequence of the accident, and (c) to decide, as a group, who was to blame.

To do the task, learners will be compelled to fulfill the conditions of a communicative activity outlined above. And, as in real life, there will always be some difference of opinion as to what exactly happened. Where there is difference of opinion and the built-in need to resolve that difference, learners will be compelled to use language in such a way that they will be distracted from a concern for formal accuracy.

c. Info-gap-race

The teachers pre-teaches or revises nouns relating to geometrical shapes, such as line, square, circle, triangle, and rectangle, as well as prepositional phrases such as on the left, on the right, above, below ... , above ..., outside ..., inside ...., so that learners can describe a design such as the following. To practice, the teacher dictates a design - that is, describes it so that the learners can draw it correctly.

For example:

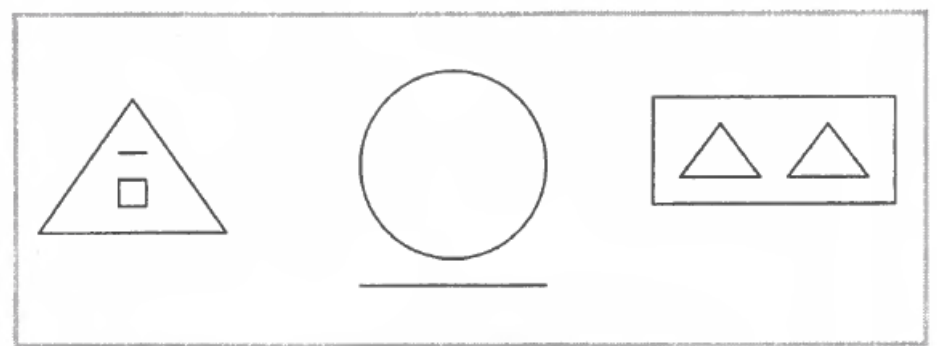

On the left there is a triangle. Inside the triangle there is a small square and above the square there is a straight line ..... the learners do the same to each other in pairs.

d. Surveys

These are simply more elaborated versions of the milling activity described earlier, and involve learners asking and answering question in order to complete a questionnaire or survey, based on a topic that the teacher has suggested, or which occurs in the coursebook.

For example:

The learners may be asked to prove or disprove the claim that men take after their fathers and women take after their mothers. The idea is that learners prepare - in pairs or small groups - survey - type questions, such as is or was your father interested in football? Are you? etc, and then mill around, asking the question, 
nothing answers, before returning to their original groups to collate their results. A spokesperson from each group then reports the groups' finding to the class, whereupon the class decides, as a group, whether the claim is justified or not.

e. Blocking games

Many of the dialogues that learners practice follow a fairly predictable route, for example, en exchange encounter at a railway station ticket office, ordering a meal in a restaurant, or a dialogue in which someone is phoning a business to ask to speak to one of its staff. Learners typically listen to, read, rehearse, and then perform the dialogues, to the point that they hardly have to listen to what their classmate is saying any more. In order to introduce an element of unpredictability into such dialogues, one of the speakers (typically the one providing a service) can be encouraged to block the other one's expectations. The teacher can demonstrate by asking one of the students to take a role.

For example:

The customer's role in a shopping situation which has been thoroughly practiced. The teacher takes the role of the shop assistant. Instead of providing the expected response (e.g. Yes certainly. What size do you take? In answer to the request: I'd like to buy a pair of trainers.) the teacher says: I'm sorry, I'm new here. What are trainers? or Have you tried our sports department? or Trainers? Don't you mean gym shoes? The customer then has to cope with this unexpected response, and any others that the shop assistant comes up with subsequently. Students can then play the blocking game in pairs themselves, exchanging roles and partners from time to time.

f. Guessing games

It is about learners think of a job and the others have to ask yes/no questions to guess what it is, provide ideal condition for automating knowledge.

For example:

The teacher asks one of the students to come forward in front of the class and to think a job. The others have to ask to the student by do you work indoors or outdoors? Do you work with your hands? Do you wear a uniform?

\section{Conclusion}

Based from finding, the main sources of anxiety are personal and interpersonal anxiety, personal belief about language learning, instructor-learner interaction, classroom procedures, and language testing (Oktaviani at al, 2013). The role of teacher is needed to minimize the anxiety in learning. Teacher has to be creative to create fun and interesting activity to minimize students' anxiety. Ewe Lin at al (2014) in their finding concluded that fun learning can minimize students' anxiety in speaking class. Qian and Seepho (2012) used jigsaw activity and Atas (2014) used drama activity. Here the writer suggests to conduct communicative tasks based on Thornburry theory because it is interesting. The students can feel happy and enjoy the activity and their anxiety can be minimized. The students can explore their language especially in English because there is no restriction on the language used here. Students can practice the language directly in the real life in their classroom activity spontaneously. Interaction among students and also between students and the teacher can be created.

\section{References}

Atas, Mine. 2014. The reduction of speaking anxiety in EFL learners through drama techniques. Elsevier. Retrieved on December 15th, 2015 from http://ac.els-cdn.com/S1877042815006023/1-s2.0-S1877042815006023main.pdf?_tid=d3991e84-a28e-11e5-bbf100000aab0f6c\&acdnat=1450117182_bed9c6986840ebac7f12163aea89aa61

Brown, H. Douglas. 2000. Principles of Language Learning and Teaching. New York: Addison Wesley Longman. Ellis, Rod. 2008. “The Study of Second Language Acquisition”. Oxford, UK. Oxford University Press.

Ewe Lin, Evelyn Yeap., Azmi, Noor Hafiza Nor., Razak, Ili Farhana Ab., Sahiddan, Nurhanis., Tong, Chong Seng., and Tarmizi, MOhd Ariff Ahmad. 2014. Fun Learning Activities: The Antidotes of Anxiety in Public Speaking Classroom. International Journal of Asian Social Science 4(2)170-176. Retrieved on December $12^{\text {th }}, 2015$ from http://www.aessweb.com/pdf-files/Ijass-\%204\%282\%29\%20170-176.pdf

Horwitz, E. K., Horwitz, M. B., \& Cope, J. 1986. “Foreign Languge Classroom Anxiety”. In Willey Blackwell. Retrived October $16^{\text {th, }} 2015$ from http://www.jstor.org/stable/327317 
Kayi, Hayriye. 2006. Teaching Speaking: Activities to Promote Speaking in a Second Language. The Internet TESL Journal. Retrieved 30th, 2015 from http://iteslj.org/Techniques/Kayi-TeachingSpeaking.html

Merc, Ali. 2011. Sources of Foreign Language Student Teacher Anxiety: A Qualitative Inquiry. Anadolu University, Turkey. Turkish Online Journal of Qualitative Inquiry. Retrieved October 16th, 2015 from files.eric.ed.gov/fulltext/ED537806.pdf

Oktaviani, Fatmala Sari., Radjab, Desmawati., \& Ardi, Havid. 2013. An Analysis of Students' English Language Anxiety at SMAn 7 Padang. Journal of English Language Teaching. Retrieved on October 15 ${ }^{\text {th }}, 2015$ from http://download.portalgaruda.org/article.php?article=100277\&val=1486

Qian, Li., Seepho, Dr. Sirinthon. 2012. Foreign Language Speaking Anxiety Reduction through a Jigsaw Activity. School of Foreign Languages, Institute of Social Technology Suranaree. University of Technology. Arab World English Journal. Retrieved on December 15, 2015 from http://www.awej.org/images/AllIssues/Volume3/VolumeeNumber4December2012/17.pdf

Richard, Jack C. Teaching Listening and Speaking: From Theory to Practice. Retrieved October $29^{\text {th }}, 2015$ from http://www.professorjackrichards.com/wp-content/uploads/teaching-listening-and-speaking-from-theoryto-practice.pdf

Thornburry, Scott. 2005. How to Teach Speaking. Pearson Longman.

Young, Dolly Jesusita. 1991. Creating a Low-Anxiety Classroom Environment: What Does Language Anxiety Research Suggest? In Willey Blackwell. Retrieved on October 16th, 2015 from https://leighcherry.wikispaces.com/file/view/Creating+a+low-anxiety+classroom+--+Young.pdf. 